\title{
Development of Technical Competency of the State Civil Apparatus at the State Civil Service and Human Resource Development Agency of Biak Numfor, Province of Papua
}

\author{
Fatmawada Sudarman $^{1}$, Djamil Hasim ${ }^{2}$, Rani Maswati ${ }^{3}$ \\ ${ }^{1}$ Public Administration, Institue of Social and Politic Science of Yapis Biak, Indonesia \\ ${ }^{2}$ Public Administration, Institue of Social and Politic Science of Yapis Biak, Indonesia \\ ${ }^{3}$ Government, Institue of Social and Politic Science of Yapis Biak, Indonesia
}

\begin{abstract}
This study aims at analyzing the development of the technical competency of the State Civil Apparatus (ASN) at the State Civil Service and Human ResourceDevelopment Agency of Biak Numfor Regency, Papua Province. The research employs descriptive research with a qualitative approach. Primary data was collected through observation, interviews and Focus Group Discussion (FGD); The respondents were the State Civil Apparatus at the State Civil Service and Human Resource Development Agency of Biak Numfor Regency, Papua Province. Secondary data was obtained through documentation studies. The data were analyzed using interactive models. The results showed that the development of technical competency of the State Civil Apparatus at the State Civil Service and Human Resource Development Agency was carried out through strengthening the knowledge and skills. More specifically, the results of this study indicate that the pattern of competency development of the State Civil Apparatus is still dominated by its irrelevance between types of development and the competencies of skills and knowledge of State Civil Apparatus who delegated to join the development program so that it affects the ability and performance of the State Civil Apparatus who have not been able to answer their duties and functions in the organization.
\end{abstract}

Keywords: Development, Technical Competency, State Civil Apparatus

\begin{abstract}
Abstrak
Penelitian ini bertujuan untuk menganalisis pengembangan kompetensi teknis Aparatur Sipil Negara (ASN) pada Badan Kepegawaian dan Pengembangan Sumber Daya Manusia Kabupaten Biak Numfor Provinsi Papua. Metode penelitian yang digunakan adalah penelitian deskriptif dengan pendekatan kualitatif. Data primer dikumpulkan melalui observasi, wawancara dan Focus Group Discussion (FGD); responden adalah Aparatur Sipil Negara pada Badan Kepegawaian dan Pengembangan Sumber Daya Manusia Kabupaten Biak Numfor Provinsi Papua. Data sekunder diperoleh melalui studi dokumentasi. Data dianalisis dengan menggunakan model interaktif. Hasil penelitian menunjukkan bahwa pengembangan kompetensi teknis Aparatur Sipil Negara pada Badan Kepegawaian dan Pengembangan Sumber Daya Manusia diwujudkan dengan melalui penguatan pada pengetahuan dan keterampilan. Lebih khusus lagi hasil dalam penelitian ini menunjukkan bahwa pola pengembangan kompetensi Aparatur Sipil Negara masih didominasi oleh tidak relevansinya antara jenis pengembangan dengan kompetensi skill dan knowledge Aparatur Sipil Negara yang diutus untuk mengikuti pengembangan sehingga berdampak pada kemampuan dan kecakapan kerja Aparatur Sipil Negara yang belum mampu menjawab tugas dan fungsinya dalam organisasi.
\end{abstract}

Kata kunci: Pengembangan, Kompetensi Teknis, Aparatur Sipil Negara (ASN)

${ }^{*}$ Penulis Korespondensi

E-mail : fatmawadha@gmail.com

Website : http://journal.unismuh.ac.id/index.php/kolaborasi 
Kolaborasi : Jurnal Administrasi Publik, April 2020 Volume 6 Nomor 1

INTRODUCTION

The Republic of Indonesia which was proclaimed on August 17, 1945, is an "independent" and "sovereign" country in national ideals, and being the part of a global system that cannot be separated from the influence and impact of the region state, both economic, political, social, culture, education, science and technology, and Human Resource (HR). The globalization, on one side, can have a negative impact such as: increasingly strengthening the dependency of weak countries against the strong one. On the other hand, it can have positive effects such as: the governance is more democratic, transparent and accountable in fulfilling social services.

In the new order era starting in 1971 until the reform era, the government never stopped vocalize the need for efforts to foster, improve and control the government officials both at the central and regional levels, which were intended to be efficient, effective, clean and authoritative and capable to carry out the general duties of government and to carry out the development smoothly, based on enthusiasm and attitudes towards the community.
Human resource as one of the elements in the organization can be interpreted as human beings that working in an organization, and to support the realization of a quality human resource process a variety of superstructure and infrastructure need to be prepared. Human resource is the whole people who work in organizations that contribute to the running of the organization. Human resource is the power of thinking and human work that is still stored in oneself, which needs to be developed, in order to be utilized as well as possible for the welfare of human life. Potential abilities possessed by humans, which consist of the ability to think, communicate, act, and be moral to carry out a technical and managerial activity. Human resource in the organization must be given full attention, especially in an environment that is completely uncertain because human resources have an important role that determines the life and death of the organization.

The human resource that referred to in the context of this study is the State Civil Apparatus (ASN) who work in the State Civil Service and Human Resource Development Agency (BKPSDM) of Biak Numfor Regency, 
Kolaborasi : Jurnal Administrasi Publik, April 2020 Volume 6 Nomor 1

Papua Province. The mandate of Law Number 5 of 2014 concerning the State Civil Apparatus, the State Gazette of the Republic of Indonesia of 2014 Number 5494 confirms that the State Civil Apparatus, hereinafter abbreviated as ASN, is a profession for civil servants and the government employees with work agreements that work for the government agencies.

The State Civil Service and Human Resource Development Agency (BKPSDM) of Biak Numfor Regency, Papua Province, has a job description and functions that refers to the Regent Regulation Number 120 of 2017. The description of the tasks and functions are including:

1. The State Civil service and Human Resource Development Agency has the task of helping the Regent in carrying out the supporting functions in the sector of staffing and developing the human resource which is the authority of the regional government.

2. In carrying out the tasks as referred to in paragraph (1), the State Civil Service and Human Resource Development Agency shall carry out the functions to: a. Formulate the technical policies in the field of staffing and human resource development.

b. Carry out the technical support tasks in the field of staffing and human resource development.

c. Do monitoring, evaluating and reporting on the implementation of tasks of technical support in the field of staffing and human resource development.

d. Guide and direct the technical policies in implementing functions supporting regional government affairs in the field of staffing and human resource development.

e. Do other functions as being ordered by the Regent in accordance with their duties and functions.

The description of the tasks and functions mentioned above is not only positioned as a handbook of guidance for members of the organization of the State Civil Service and Human Resource Development Agency (BKPSDM) of the Biak Numfor Regency, Papua Province but also as one of the guidelines in the realization of work productivity. In addition, in carrying out the duties and functions of 
Kolaborasi : Jurnal Administrasi Publik, April 2020 Volume 6 Nomor 1

the State Civil Service and Human Resource Development Agency (BKPSDM) of Biak Numfor Regency, Papua Province. Of course, it must be supported by professional and reliable human resources so that better quality public services can be achieved.

Organizations or agencies that want to stay progressive, developing and have a positive image in the eyes of the public will not ignore the aspect of developing the quality of their human resource. According to Akib (2011:241) that the expected organizational transformation is not like what was allegedly "just old wine in a new bottle", only as old wine in a new bottle. However, organizational transformation actually occurs as a heuristic, that is, a scientific process to normalize human creative behavior in knowledge-based organizations.

One of the targets that can be used for leaders in order to carry out the investments and attention to human resources within the organization is to develop these human resources. Development is a learning process that is designed in order that the employees can develop, the purpose of development is not only to improve the employees' performance now but also to focus on the long term and to help employees prepare the jobs in the future.

Suwatno \& Priansa (2016:103) suggests that "development is defined as the preparation of individuals to assume different or higher responsibilities within the organization". Development is usually associated with an increase in intellectual or emotional abilities needed to do a better job. Development stand on the fact that an employee needs knowledge, expertise, and abilities that develop in order to work well in the succession of positions he has undergone during his career.

The development of human resource refers to the problems of staff and personnel which are to maintain and improve the employees' competencies in order to achieve organizational effectiveness. Development is a systematic and organized procedure with general and conceptual and theoretical learning processes for general purposes. As stated by Welbourne (2011:659), "the essence of HRM is "creating opportunities for people at work to be successful". Human resource development includes activities directed towards organizational and individual learning. 
Kolaborasi : Jurnal Administrasi Publik, April 2020 Volume 6 Nomor 1

Human resource development is manifested in activities aimed at changing organizational behavior.

Human resource development shows an intentional effort with the aim of changing the behavior of organizational members or at least increasing the ability to change. So, the main characteristic of human resource development is activities that lead to behavior change. Human resource development is all activities carried out by organizations in facilitating employees to have the knowledge, expertise, and attitudes needed to handle current or future work. The activity in question, not only in the aspects of education and training, but involves aspects of career and organizational development. In other words, the development of human resources is closely related to efforts to improve the knowledge, abilities, and / or attitudes of organizational members and the provision of career paths that are supported by organizational flexibility in achieving organizational goals.

In article 70 of Law Number 5 of 2014 states that "every ASN has the opportunity to develop their competencies". Azmy (2015:223) states that competence is a characteristic in which individuals have the ability and are used in a consistent manner appropriate to achieve the desired performance. Competency development is the development given to employees to increase the knowledge, skills, abilities, attitudes, and appreciation needed in carrying out their duties professionally, effectively and efficiently. In this study, the focus was more on ASN with Civil servant status. Article 69 of Law Number 5 of 2014 confirms that one of the Civil Servants competency qualifications is technical competency, which is measured by the level and specialization of education, training, functional technicality.

Based on what happen currently, it shows that the technical competency possessed by the ASN at the State Civil Service and Human Resource Development Agency (BKPSDM) of Biak Numfor Regency, Papua Province has not supported the employees yet to carry out their functions within the organization. From the illustrated data, the level of education of the State Civil Apparatus at the State Civil Service and Human Resource Development Agency of Biak Numfor Regency, Papua Province shows that as many as 47 employees, 13 employees (27.65\%) 
Kolaborasi : Jurnal Administrasi Publik, April 2020 Volume 6 Nomor 1

have relatively low educational background, 2 employees (3, 57\%) of whom are employees who occupy positions as Head of Sub-Sector, (Data Source: the Sub-Sector of Data and Information of BKKDM Biak Numfor Regency in 2020).

These problems have an impact on the implementation of operational activities where there are still some ASNs that have not been responsive in providing services, as well as the low level of discipline of ASN such as ASN who often arrive late and leave the place during working hours. As a result, it has an impact on public services. As often as people can be seen waiting for a long time to get the desired service.

From the description of the condition of the human resource of the apparatus at the State Civil Service and Human Resource Development Agency (BKPSDM) above, this study analyzes the development of technical competency at the State Civil Service and Human Resource Development Agency (BKPSDM) of Biak Numfor Regency, Papua Province.

\section{RESEARCH METHODS}

This type of research is a descriptive study with a qualitative approach. This approach is used to find in-depth information and understand phenomena that are occurring naturally regarding the development of technical competencies in the BKPSDM of Biak Numfor Regency, Papua Province. The type of data used in this study consists of primary data and secondary data. Primary data through direct observation to the location of the study conducted from September 2019 by looking at matters relating to the object of research such as the implementation of the development of technical competencies and then making notes to obtain a clearer picture and providing clues to support further processed data. Furthermore, interviews conducted in the pre-study from September 2019 and in-depth interviews conducted by researchers in the research process to obtain information from competent informants related to the development of technical competencies using the guided interview technique conducted by the interviewer in December 2019 with a series of complete questions and in detail, the informants were 10 State Civil Apparatus and 1 of them was the key informant. The selection of the 10 informants was based on the criteria that the informant was an employee who 
Kolaborasi : Jurnal Administrasi Publik, April 2020 Volume 6 Nomor 1

worked long enough for the BKPSDM of Biak Numfor Regency and had direct activities with the objects to be studied so that they were believed to be able to provide the information needed related to research. The informants in this study consisted of Head of Subdivision, Head of Division, Head of Sub-Sector, Secretary, Staff and Head of Agency who acted as key informants. The election of the Head of the Agency as a key informant on the grounds that the Head of the Agency is the highest leader who can provide more accurate information related to the development of technical competencies in the BKPSDM of Biak Numfor Regency. In addition to through direct observation and interviews, primary data was also obtained through questionnaires related to the development of cultural social competencies that were shared with respondents during interviews. Data collection techniques were also conducted through Focus Group Discussion (FGD) to draw conclusions on subjective meanings that are difficult to give their own meaning by researchers related to the development of technical competencies in BKPSDM of Biak Numfor Regency, while participants were active in Focus Group
Discussion (FGD) is a Civil Apparatus that rarely even has ever received the development of technical competencies consisting of 6 State Civil Apparatus. For secondary data, the researchers collected data from the State Civil Apparatus at the BKPSDM in Biak Numfor Regency, the data collected from the Head of the Data and Information Sub-Sector, and the Head of the General and Employees Subdivisions. In addition, secondary data is also obtained from scientific writing (related books / literature, reports, scientific works and relevant research results).

\section{RESULTS AND DISCUSSION}

Development of human resources is a condition that must exist within an organization. The development of human resources is an effort carried out in an organization to improve performance and for employee growth, as well as increasing intellectual capacity needed to carry out better work in the organization. Chalofsky (2014) argues that "human resource development is interpreted as a study and practice of increasing the learning capacity of individuals, groups and organizations through the 
Kolaborasi : Jurnal Administrasi Publik, April 2020 Volume 6 Nomor 1

development and application of learning-based interventions with the aim of optimizing the growth and effectiveness of people / employees and organizations".

Article (69) of Law Number 5 of 2014 affirms that one of the ASN competency qualifications is technical competency that measured from the level and specialization of education, training, functional technical.

Based on the results of interviews with informants (IA) as a Staff for Employees Development at the BKPSDM of Biak Numfor Regency, Papua Province (interview, 09 July 2018) states that the development of technical competencies that have been provided such as training in functional positions, employees auditors and functional team and education auditors.

In addition, (FDS) as Staff for Procurement and Dismissal of Employees at the BKPSDM of Biak Numfor Regency, Papua Province (interview, 10 July 2018) said that the development of technical competencies that have been given to employees is through education (study delegation and learning assignments), and specifically for study assignments that are funded by the Regional Government (PEMDA) because there are some Universities that are outside the region in collaboration with the Regional Government (PEMDA) of Biak Numfor Regency so that employees can be sent to study at the University. Furthermore, the development of technical competencies such as the use of Information and Technology (IT).

Furthermore, the opinion of (BAE) as the Head of the General Subdivision of Staffing at BKPSDM of Biak Numfor Regency, Papua Province (interview, 10 July 2018) said that the development of technical competencies has been given to several employees at BKPSDM of Biak Numfor Papua Province, like functional technical training, with a development model adapted to the rules or regulations of the Institute of Public Administration (LAN) such as using a new pattern, the development has gone well but returning to employees how they are given development can apply what which they get in the process of developing these competencies into their jobs.

Similarly the interview with $(\mathrm{JRW})$ as the Head of the Sub-Sector for Competency Development at the BKPSDM of Biak Numfor Regency, 
Kolaborasi : Jurnal Administrasi Publik, April 2020 Volume 6 Nomor 1

Papua Province (interview, 11 July 2018) said that so far the development of technical competencies had been given to employees through training level leadership the first, the second, third and fourth level, which can be known as the PIM, the third level of PIM for the head of the Division or Secretary and the fourth level of PIM for the head of the Sub Division.

The same opinion from (JR) as Secretary of the BKPSDM of Biak Numfor Regency, Papua Province (interview, 11 July 2018) said that the development of technical competencies that have been provided is structural training given annually to employees, in structural training there some parts of the government's financial technical mission, technical expenditure on goods and services. Furthermore, the development of technical competencies such as education and training, but the implementation is not optimal because there are several employees who are given the development of education and training that are not in accordance with their field of work.

Similar with (JR), (PO) as the Head of Apparatus Development Division at the BKPSDM of Biak Numfor Regency, Papua Province (interview, 09 July 2018) said that the development of employee technical competencies which had been implemented in 2016 was technical training staffing, financial technical training and Technical Guidance (BIMTEK). The development has been given but the implementation has not yet been optimal and there should be monitoring for its main employees at the level of discipline in terms of time and that are still low in performance.

Furthermore, the opinion of (DF) the Staff of the Mutation Division at BKPSDM of Biak Numfor Regency, Papua Province (interview, 13 July 2018) said that the development of technical competencies which had been provided in the form of seminars and workshops. Although the implementation sometimes does not touch on the understanding of each employee, so far, the material given when training is good, but sometimes the employees who are sent to participate in the training activities are out of sync with the type of training being implemented. Other problems such as the implementation of development should consist of theory and practice, but so far the implementation of development is not 
Kolaborasi : Jurnal Administrasi Publik, April 2020 Volume 6 Nomor 1

run so because of constraints with support such as Wi-Fi networks and the presence of several employees who do not carry facilities such as laptops during the development program, so that what is given during development cannot support the implementation tasks and functions in the organization.

A different opinion by (AM) as the Head of the Procurement Data and Information Sub-Division at the BKPSDM of Biak Numfor Regency, Papua Province (interview, 09 July 2018) said that for the past 2 years there had never been a development of technical competencies. Regarding this development, it has been given to other parts, such as in the ranks there are three employees who follow the employee auditor this year. But in our field the field of procurement of data and information for the implementation of this development has never been carried out again, and so far we have worked according to what we know only or self-study to develop capabilities related to our Main Tasks and Functions (TUPOKSI) especially related to the employee information.

Agree with (AM)'s opinion, (AR) as the Head of the Mutation SubDivision at the BKPSDM of Biak
Numfor Regency, Papua Province (interview,10 July 2018), said that the implementation of technical competency development since a few years ago was often carried out and given to employees but for now the development has never been given.

To obtain the validity of the data, the researcher then triangulated by conducting interviews with (IPW) as the Head of the BKPSDM of Biak Numfor Regency, Papua Province (interview, 18 July 2018) which stated that the development of technical competencies given to employees was through assignments study, seminar and Technical Guidance (BIMTEK). The development is right even though the implementation has not been maximized. However, in order to make the employees to work better, I, as a leader of the State Civil Service and Human Resource Development Agency of Biak Numfor Regency, Papua Province applies a pattern of guidance in the form of reward and punishment for employees so that they can be more active in their work, even though the implementation is not optimal.

The same thing was stated by several State Civil Apparatus in the BKPSDM through a Focus Group 
Kolaborasi : Jurnal Administrasi Publik, April 2020 Volume 6 Nomor 1

Discussion (FGD) which said that "the development of technical competencies has been given to the State Civil Apparatus at the BKPSDM of Biak Numfor Regency Province Papua such as training, seminars, workshops, and Technical Guidance (BIMTEK), as well as formal technical competency development through education which consists of study delegation and study assignments. However, to form the technical competency of the State Civil Apparatus at the BKPSDM of Biak Numfor Regency, it must pay attention to the relevance between competencies possessed by the State Civil Apparatus that assigned to join the development program with the type of development that is implemented using the appropriate development model with rules or regulations so that the development pattern is able to answer the tasks and functions of the State Civil Apparatus in the BKPSDM of Biak Numfor Regency, Papua Province.

In relation to the data obtained at the research location, it has been shown that so far there have been efforts made in developing the employees' technical competencies in BKPSDM, by strengthening the skills and knowledge. Skills are demonstrated by the implementation of training, namely functional technical training and government financial structural technical training and structural technical training, staff auditors, seminars, workshops, Technical Guidance (BIMTEK), and courses on Information and Technology (IT). Furthermore, the development of technical competencies that have been provided by strengthening knowledge is demonstrated by the implementation of formal competency development through education which consists of study permits and study assignments.

Competency is a determining factor for someone in producing good performance and also the success of the organization in achieving the goals. Competence as a person's observable ability that includes knowledge, skills and attitudes in completing a job or task in accordance with specified performance, of Sartika \& Kusumaningrum, (2017:134).

The importance of the competency of the apparatus in an organization is basically related to the problem of human resources (human factors) in the life of the organization. In any organization, including public organizations (government 
Kolaborasi : Jurnal Administrasi Publik, April 2020 Volume 6 Nomor 1

organizations), the existence of elements of human resources will determine the ability of the organization in optimizing the achievement of the goals and objectives of the organization. Therefore, the important role of human resources in the organization will only be optimal if the existing resources have sufficient competence to carry out the functions carried out by the organization.

Competency-based human resource development is carried out in order to provide results in accordance with the goals and objectives of the organization with predetermined performance standards. Competencies possessed by an employee individually must be able to support the implementation of the organization's vision and mission through the organization's strategic performance. Therefore, individual performance in the organization is a way of increasing the productivity of the organization itself. As stated by Radhakrishna \& Satya Raju (2010:33) that "performance is the key driver of success, which will lead to survival of organizations".

In simple terms, competency is defined as a set of abilities that include knowledge, attitudes, values and skills that must be possessed by a person in order to carry out the main tasks, functions and responsibilities of the job and / position he carries. The word basically is competent, means capable, qualified or skilled. Competency as a person's ability to produce at a satisfactory level in the workplace, including a person's ability to transfer and apply these skills and knowledge in new situations and increase agreed benefits.

In the Regulation Number 11 of 2017 concerning the Management of Civil Servants of the Republic of Indonesia State Gazette of 2017 Number 63 confirms that technical competency is knowledge, skills, and attitudes/behaviors that can be observed, measured, and developed specifically related to the technical field of position.

The development of technical competencies is very important in increasing the productivity of the State Civil Apparatus which can have an impact on the quality of better performance. In the results of the study indicate that efforts in improving the technical competency of the State Civil Apparatus in the State Civil Service and Human Resource Development Agency 
Kolaborasi : Jurnal Administrasi Publik, April 2020 Volume 6 Nomor 1

have not shown tangible results for the improvement of the technical competency of the State Civil Apparatus.

Generally, the implementation of the development of technical competencies related to structural training in education through training and education is in accordance with the duties of the State Civil Apparatus at the BKPSDM as indicated by the implementation of third level leadership training for heads of fields or secretaries and fourth level leadership training for heads the sub-section shows that the implementation of the development is not relevant to skill competency and know-how, so that it has an impact on the results of competency development that cannot be implemented in structural positions. In accordance with Article 9 of the Government Regulation Number 101 of 2000 concerning position education and training for civil servants, it is confirmed that leadership training, hereinafter referred to as Diklat PIM, is carried out to achieve leadership competency requirements of government rules that are in line with structural positions. On these issues also have an impact on the equitable development of competencies of the
State Civil Apparatus in BKPSDM. Therefore, improve the performance of the State Civil Apparatus at the BKPSDM, development should be provided with aspects of equitable development to avoid divisions within the organization, where such divisions can have an impact on decreasing the capacity of services provided. Meanwhile, the key to the success of competency-based human resource development is the leadership's commitment to creating conducive conditions for employees of Efendi (2015:9).

Other problems which are also found in the implementation of the development of the technical competency of the State Civil Apparatus in the BKPSDM are constrained by the limited facilities that have an impact on the accuracy and accuracy of the development of competencies in the State Civil Apparatus. So far, the leadership of BKPSDM has implemented a pattern of guidance in the form of reward and punishment in an effort to increase the technical competency of the State Civil Apparatus, but it is recognized that the implementation has not been maximized. In Nugroho (2015:6), 
Kolaborasi : Jurnal Administrasi Publik, April 2020 Volume 6 Nomor 1

writings (2015: 6), it is emphasized that "to motivate the others, can be given a number of treatments, one of the way is to provide rewards in accordance with individual and organizational needs, and punishment as a consequence and a way to direct a behavior in order that it is fit the behavior in general".

To improve the performance of the State Civil Apparatus at the BKPSDM, leaders should renew the system of punishment implementation so that employees can work optimally and have motivation in their work. In addition, an important thing that must be considered is how to review the reward that is not only with social rewards but psychics rewards such as praise, flattery, and congratulations that can be felt by employees as a form of recognition of themselves and get satisfaction for themselves.

To form the technical competency of the State Civil Apparatus at the BKPSDM which can assist in the implementation of tasks and functions for the achievement of organizational goals, the pattern of training implementation is not only enough through strengthening the skills and knowledge, but how the implementation of the development is relevant to skill competency and knowhow, by using a development model that is adjusted to the rules or regulations, while considering the condition of the infrastructure, and using new development patterns that can form the employees' behavior who has the ability and credibility of desired employees who can work in accordance with the Main Tasks and Functions (TUPOKSI) in the organization. In accordance with the opinion of Mulyono (2015:22) that every development of the human resources is directed to achieve optimal growth and better service for the society.

\section{CONCLUSION}

The development of technical competency has been given to the State Civil Apparatus at the State Civil Service and Human Resource Development Agency of Biak Numfor Regency, Papua Province. However, the development program has not been able to answer the ability of State Civil Apparatus to have an impact on aspects of the equity of development. In addition, the quality of public services given to the public are not in accordance with competency standards of the State Civil Apparatus. Besides, 
Kolaborasi : Jurnal Administrasi Publik, April 2020 Volume 6 Nomor 1

the model of development between the implementation of development with the employees' skills and knowledge competencies who delegated to take part in the development program must be relevance and become the important concern to improve the technical competency of the State Civil Apparatus that can form knowledge, skills or abilities so that the professional quality standards at work can be achieved.

\section{ACKNOWLEDGMENT}

This research is supported by the Institute of Social and Politic Science (IISIP) YAPIS Biak Papua, and the civil service and Human Resource Development Institution of Biak Numfor Regency, Papua Province. I would like to thank all the colleagues who have supported this research, both with moral support and facilitate the writer so that this research could be conducted very well.

\section{REFERENCES}

Akib, H. (2011). Mencermati Heuristik Transformasi Organisasi. Jurnal Manajemen Usahawan Indonesia, 40 No. 3(241), 1.

Azmy, A. (2015). Pengembangan
Kompetensi Sumber Daya Manusia untuk Mencapai Career Ready Professional di Universitas Tanri Abeng. Binus Business Review, 6(2), 220. https://doi.org/10.21512/bbr.v6i2.9 71

Chalofsky, N. (2014). Handbook of Human Resource Development. In T.S. Rocco, \& M.L. Morris (ed). New Jersey: John Wiley \& Sons.

Efendi, N. (2015). Pengembangan Sumber Daya Manusia Berbasis Kompetensi di Kantor Pemerintah Kota Bandar Lampung. Mimbar, 31(1).

Government Regulation Number 101 of 2000 concerning position education and training for civil servants.

Law Number 5 of 2014 concerning the State Civil Apparatus.

Mulyono, A. (2015). PENGEMBANGAN KAPASITAS APARATUR SIPIL NEGARA DI DAERAH. JKMP (Jurnal Kebijakan Dan Manajemen Publik), 3(1), 17. https://doi.org/10.21070/jkmp.v3i1 .186

Nugroho, A. D. (2015). Pengaruh Reward dan Punishment terhadap Kinerja Karyawan PT Business Training and Empowering Management Surabaya. Jurnal Maksipreneur: Manajemen, Koperasi, Dan Entrepreneurship, 4(2), 4. https://doi.org/10.30588/jmp.v4i2. 100

Radhakrishna, A., \& Satya Raju, R. (2010). A Study on the Effect of Human Resource Development on Employment Relations. IUP 
Kolaborasi : Jurnal Administrasi Publik, April 2020 Volume 6 Nomor 1

Journal of Management Research, $X I V(3), 30$.

Regulation Number 11 of 2017 concerning the Management of Civil Servants of the Republic of Indonesia State Gazette of 2017 Number 63.

Regulation Number 120 of 2017 Biak Numfor Regency, Papua Province concerning a job description and functions.

Sartika, D., \& Kusumaningrum, M. (2017).

Pengembangan

Kompetensi Aparatur Sipil Negara di Lingkungan Pemerintah Provinsi Kalimantan Timur. Jurnal Borneo Administrator, 13(2), 144. https://doi.org/10.24258/jba.v13i2. 310

Suwatno, \& Priansa, D. J. (2016). Manajemen SDM dalam Organisasi Publik dan Bisnis. Bandung: Alfabeta.

Welbourne, T. M. (2011). Editor-inchief's note: The next 50 years of Human Resource Management: Moving forward faster and together. Human Resource Management. 